\title{
Microalgae Growth and Phosphorus Uptake of Chlamydomonas Reinhardtii 11/32C under Different Inorganic Nitrogen Sources
}

\author{
Anie Yulistyorini $^{1 *}$, M. A. Camargo-Valero ${ }^{2}$ \\ ${ }^{1}$ Civil Engineering Department, Faculty of Engineering, \\ Universitas Negeri Malang, Jl. Semarang No. 5, Malang, 65145, INDONESIA \\ ${ }^{2}$ BioResource Systems Research Group, School of Civil Engineering, \\ University of Leeds, Leeds LS2 9JT, UNITED KINGDOM \\ *Corresponding Author
}

DOI: https://doi.org/10.30880/ijie.2020.12.09.030

Received 12 July 2020; Accepted 28 November 2020; Available online 30 December 2020

\begin{abstract}
Microalgae have been proven to be effective in utilizing nitrogen $(N)$ and phosphorus $(P)$ from a wide range of wastewater sources. This ability enhances the potential role that microalgae may have not only in wastewater bioremediation, but also in algal biomass production as an alternative feedstock for biodiesel and bio-fertilizer production. To investigate the ability of microalgae at recovering nutrients, the microalga strain Chlamydomonas reinhardtii $11 / 32 \mathrm{C}$ was selected to determine $\mathrm{P}$ uptake rates. Results shown that C.reinhardtii $32 \mathrm{C}$ cultivated in combination of $\mathrm{NO}_{3}{ }^{-}$and $\mathrm{NH}_{4}{ }^{+}$as nitrogen sources was able to uptake $0.067 \mathrm{mg} \mathrm{P}^{-1} \mathrm{~d}^{-1}$. Combination of both nitrogen can produce specific growth rate of $0.128 \mathrm{~d}^{-1}$ and $89 \mathrm{mg} \mathrm{VSS}^{-1} \mathrm{~d}^{-1}$ of biomass dry weight. These value is the highest compare to C.reinhardtii $32 \mathrm{C}$ cultivated in $\mathrm{NO}_{3}{ }^{-}$or $\mathrm{NH}_{4}{ }^{+}$. These findings are fundamental to understand and plan future studies for cultivation conditions to induce luxury nutrient uptake by selected microalga.
\end{abstract}

Keywords: Algal growth, C. reinhardtii, P uptake

\section{Introduction}

Eukaryotic microalga is a simple multicellular microorganism which can grow in severe environmental condition [1]. Microalgae provide an essential characteristic in their multi-purpose function, for instance, in tertiary wastewater treatment, food production, feed and chemicals [2]. The major problem of wastewater contains a high concentration of nutrients, mainly $\mathrm{N}$ and $\mathrm{P}$ in which require high cost for a chemical treatment to remove them during wastewater treatment [3]. Microalgae provide a sustainable system for nutrient removal because of their ability to assimilate nutrient and organic carbon. The algae have their potential feature in bioremediation options and also in algal biomass production as an alternative feedstock for bio-fertilizer production [4].

In the previous studies, microalga showed to be able to remove nutrient from various wastewater sources. Chlorella sp and Chlorella vulgaris removed $\mathrm{N}$ and $\mathrm{P}$ from wastewater by a removal efficiency from 76 to $83 \%$ for $\mathrm{N}$ and from 63 to $75 \%$ for $\mathrm{P}$ in digested manure [5]; 55 to $88 \%$ for $\mathrm{N}$ and 12 to $100 \%$ for $\mathrm{P}$ in municipal wastewater [6]; and 30 to $95 \%$ for $\mathrm{N}$ and 20 to $55 \%$ for $\mathrm{P}$ in industrial wastewater [7]. Furthermore, microalgae have been employed as a bio-fertilizer. Faheed and his co-workers [8] observed that dried microalgae could act as a soil additive which improves plant nutrients. 
Another study also examines the effect of blue-green algae as a bio-fertilizer to enhance yield and mineral composition of the rice plant. This application can improve $\mathrm{N}$ soil status through atmospheric $\mathrm{N}$ fixation [9].

As wastewater may contain different forms of $\mathrm{N}$ sources (e.g. Nitrate, Ammonium), it is crucial to understand the effect of various $\mathrm{N}$ sources on microalgae growth and nutrient uptake rate [10]. As observed by Tam and Wong [11] and Larsdotter [12], Ammonium is the preferred compound of $\mathrm{N}$ source for microalgae as a redox reaction is not incorporated in its nutrient assimilation [13]. However, Fernandez and Galvan [14] have studied that nitrate is more abundant in the environment mainly in natural soils, and its utilization became fundamental pathways in incorporating the macronutrient of $\mathrm{N}$ in living organisms.

This study was conducted to investigate the ability of green microalgae $C$. reinhardtii $32 \mathrm{C}$ in recovering nutrients primarily to determine $\mathrm{N}$ and $\mathrm{P}$ uptake rates under different of nitrogen sources (e.g. $\mathrm{NO}_{3}{ }^{-}, \mathrm{NH}_{4}^{+}, \mathrm{NO}_{3}{ }^{-}$, $\mathrm{NH}_{4}^{+}$). The results of this study are essential to conducting further research for enhancing luxurious nutrient accumulation in algal cells by applying a wide range of environmental factors and selected nitrogen sources.

\section{Materials and Method}

The algae cultivated in Bold's Basal Medium (BBM) and placed in a 2.5 litre of tubular photobioreactors (PBRs). Three PBRs were set containing (i) $\mathrm{NO}_{3}{ }^{-}$, (ii) $\mathrm{NH}_{4}{ }^{+}$and (iii) a mix of $\mathrm{NO}_{3}{ }^{-}$and $\mathrm{NH}_{4}{ }^{+}$as nitrogen sources in $\mathrm{BBM}$ used for these experiments (Fig. 1). The algae sample were taken for every two days over the cultivation time of 14 days. Then the sample was analyzed for TSS, VSS, organic-N, and organic-P. The remaining nutrient concentration in the solution was also analyzed for $\mathrm{NO}_{3}{ }^{-}, \mathrm{NH}_{4}{ }^{+}$and $\mathrm{PO}_{4}{ }^{3-}$ concentration. $\mathrm{NO}_{3}{ }^{-}$was analyzed by using ion chromatography $(850$ Professional IC Metroohm) and the other parameters were analyzed according to standard methods for the examination of water and wastewater (APHA, 2012) [15] as listed in Table 1.

Table 1 - Standard methods for wastewater sample examination

\begin{tabular}{ccl}
\hline No & Parameters & Method Code* \\
\hline 1 & TSS & 2540 D,E \\
2 & VSS & 2540 D,E \\
3 & Org-N & TKN-4500-Norg \\
4 & Org-P & $4500-\mathrm{P}, \mathrm{B}$ \\
5 & $\mathrm{NH}_{4}{ }^{+}$ & $4500-\mathrm{NH}{ }_{3} \mathrm{~B}, \mathrm{C}$ \\
6 & $\mathrm{PO}_{4}{ }^{3-}$ & $4500-\mathrm{P}, \mathrm{E}$ \\
\hline
\end{tabular}

*Standard methods for the examination of water and wastewater (APHA, 2012), unless otherwise stated

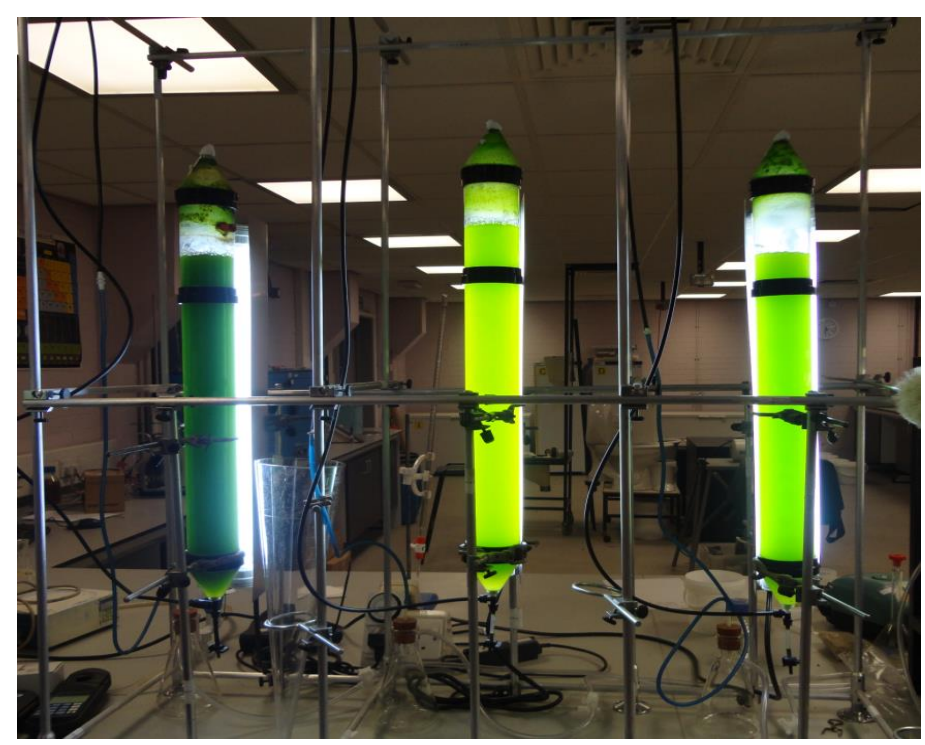

Fig. 1 - C.reinhardtii 11/32C cultivation with different nitrogen sources: $\mathrm{NO}_{3}^{-}$(left), $\mathrm{NH}_{4}^{+}$(center), and a mix of $\mathrm{NO}_{3}{ }^{-}$and $\mathrm{NH}_{4}{ }^{+}$(right) 
$25 \mathrm{gr} \mathrm{l}^{-1}$ of $\mathrm{NaNO}_{3}$ and $10 \mathrm{gr} \mathrm{l}^{-1}$ of $\mathrm{NH}_{4} \mathrm{Cl}$ used as $\mathrm{N}$ sources and followed by $1.41 \mathrm{mg}$ of $\mathrm{K}_{2} \mathrm{HPO}_{4}$ and $3.29 \mathrm{mg}$ $\mathrm{KH}_{2} \mathrm{PO}_{4}$ used as $\mathrm{P}$ sources. The following environmental conditions were set to these experiments: $100 \mathrm{mg} \mathrm{N}^{-1}, 1 \mathrm{mg} \mathrm{P}$ $\mathrm{l}^{-1}$; photoperiod $12 \mathrm{hr}$ light: $12 \mathrm{hr}$ dark; and light intensity $250 \mu \mathrm{E} / \mathrm{m}^{2} \mathrm{~s}$.

\section{Results}

\subsection{Effect of Inorganic Nitrogen Source on Algae Growth and Biomass Productivity}

Different $\mathrm{N}$ sources (e.g., (1) $\mathrm{NO}_{3}{ }^{-}$and $\mathrm{NH}_{4}{ }^{+}$; (2) $\mathrm{NO}_{3}{ }^{-}$; and (3) $\mathrm{NH}_{4}{ }^{+}$) were used to investigate the effect of $\mathrm{N}$ source on the algal growth rate, $\mathrm{P}$ uptake and biomass production. As shown in Fig. 2, algal growth rate and biomass productivity increased during the exponential growth phase (between days 4 and 12). The exponential growth phase was confirmed by linear correlation of transformed data (Ln VSS v time) with a resulting $\mathrm{R}^{2}$ value of 0.99 , which gave confidence when calculating specific algal growth rates.

Results showed that there was no significant difference in microalgae growth and biomass production under different $\mathrm{N}$ sources $(p>0.05)$. However, specific algal growth rates and biomass productivity cultivated in a media containing both $\mathrm{NO}_{3}{ }^{-}$and $\mathrm{NH}_{4}{ }^{+}$(experiment 1) was always higher than the figures reported for $\mathrm{NO}_{3}{ }^{-}$and $\mathrm{NH}_{4}{ }^{+}$on their own (experiments 2 and 3, respectively). The specific algal growth rates were $0.128 \mathrm{~d}^{-1}, 0.117 \mathrm{~d}^{-1}$, and $0.106 \mathrm{~d}^{-1}$ for experiments 1,2 , and 3 , respectively.

Algal biomass productivity for experiment $1\left(\mathrm{NO}_{3}{ }^{-}\right.$and $\mathrm{NH}_{4}{ }^{+}$mix $)$was $89 \mathrm{mg} \mathrm{VSS} \mathrm{l}^{-1} \mathrm{~d}^{-1}$, while the figures for algae grown in media containing only $\mathrm{NO}_{3}^{-}$or $\mathrm{NH}_{4}{ }^{+}$were 79 and $62 \mathrm{mg} \mathrm{VSS}^{-1} \mathrm{~d}^{-1}$, respectively. In practical terms, it seems that C.reinhardtii $11 / 32 \mathrm{C}$ became better when using a combination of $\mathrm{NO}_{3}{ }^{-}$and $\mathrm{NH}_{4}{ }^{+}$. Effect of six different nitrogen source and concentration were also tested on microalgae growth of Scenedesmus bijugatus. The algae grew well in all nitrogen sources, but maximum growth was reported for $\mathrm{KNO}_{3}$ [16], similarly in Botryococcus braunnii [17]. $\mathrm{NH}_{4}^{+}$also showed to trigger the optimum growth and lipid content of marine microalgae of Ellipsoidion sp. during pre-logarithmic phase [18].

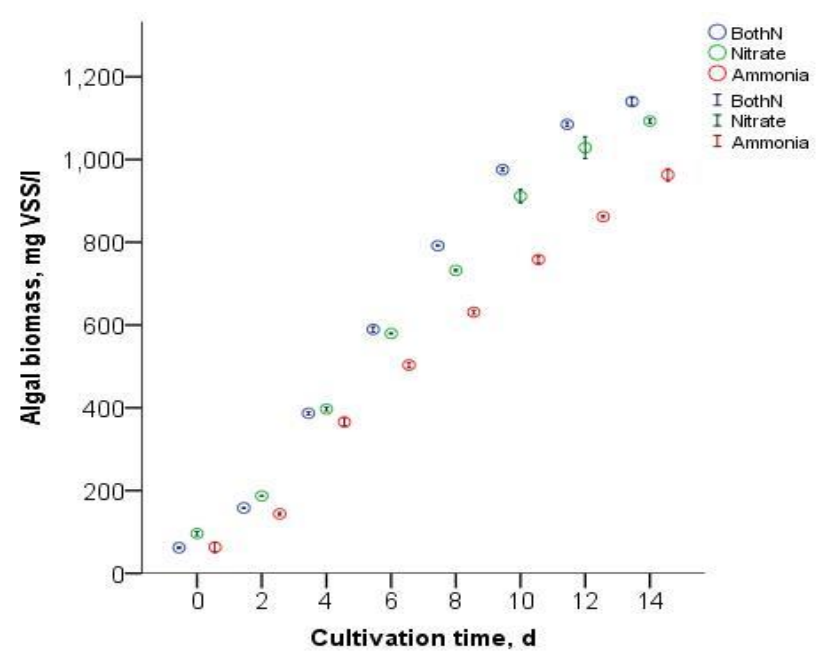

(a) Algal biomass concentration of C.reinhardtii 11/32C in different $\mathrm{N}$ sources
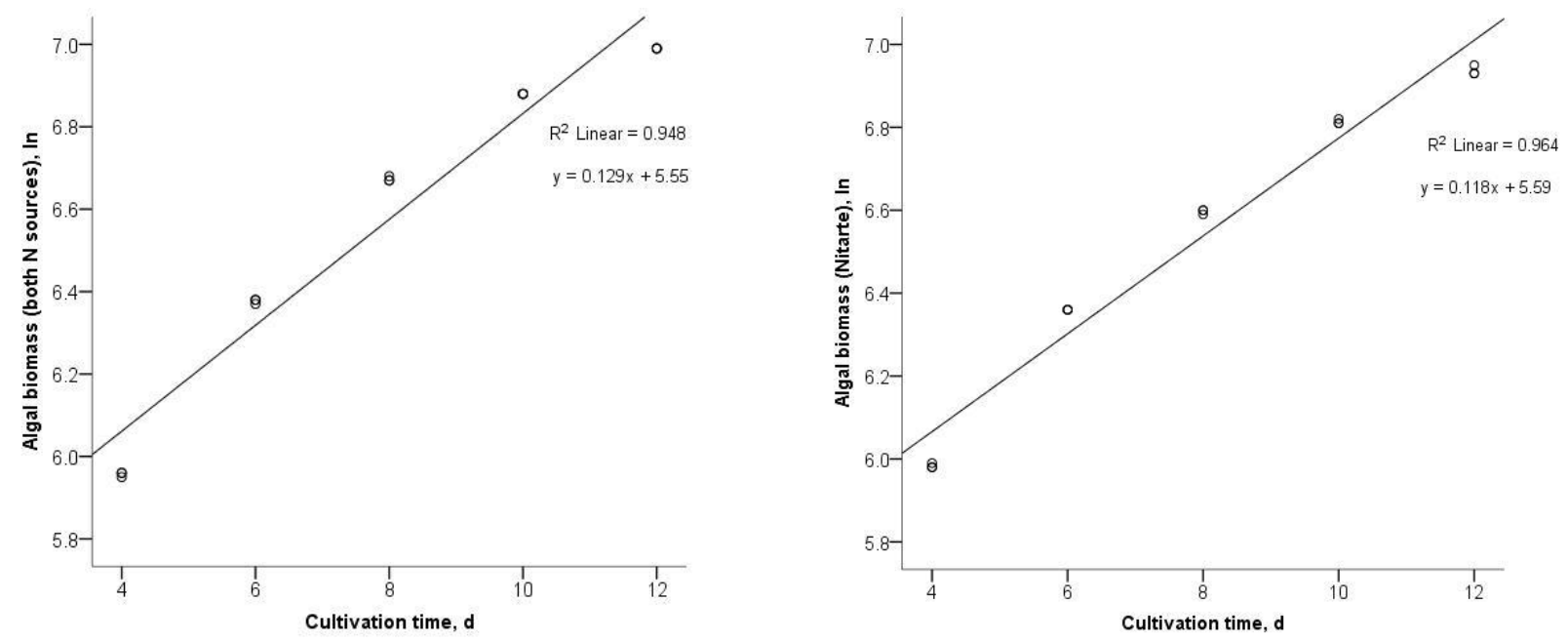
(b) The specific growth rate of C.reinhardtii $11 / 32 \mathrm{C}$ in both $\mathrm{N}$ sources
(c)The specific growth rate of C.reinhardtii 11/32C in

$\mathrm{NO}_{3}{ }^{-}$

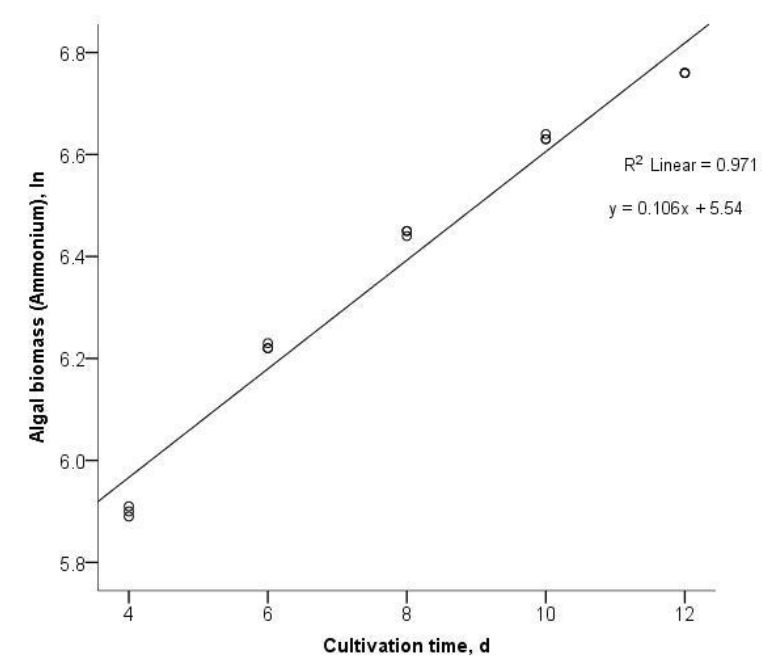

(d) The specific growth rate of C.reinhardtii 11/32C in $\mathrm{NH}_{4}^{+}$

Fig. 2 - Algal biomass and specific growth rate of C.reinhardtii 11/32C using different nitrogen sources

Fig. 3 shows that C.reinhardtii $11 / 32 \mathrm{C}$ preferred to take up $\mathrm{NH}_{4}{ }^{+}$over $\mathrm{NO}_{3}{ }^{-}$with a total ammonium removal from the media of $97 \%$. However, the specific growth rate and biomass productivity of C.reinhardtii $11 / 32 \mathrm{C}$ grown found in experiment 3 is lower than those found in experiments 1 and 2. Also, algae have shown to consume less $\mathrm{NO}_{3}{ }^{-}$from the media with an average $\mathrm{N}$ reduction of $45 \%$. This study thus has been demonstrated that C.reinhardtii 11/32C produced a higher specific growth rate and biomass productivity when cultivated with a mix of $\mathrm{NO}_{3}{ }^{-}$and $\mathrm{NH}_{4}{ }^{+}$in the culture media (Experiment 1). That could imply the convenience of using the effluent from a conventional activated sludge process (i.e., no extended aeration for full nitrification) as the perfect culture media concerning algal biomass production.

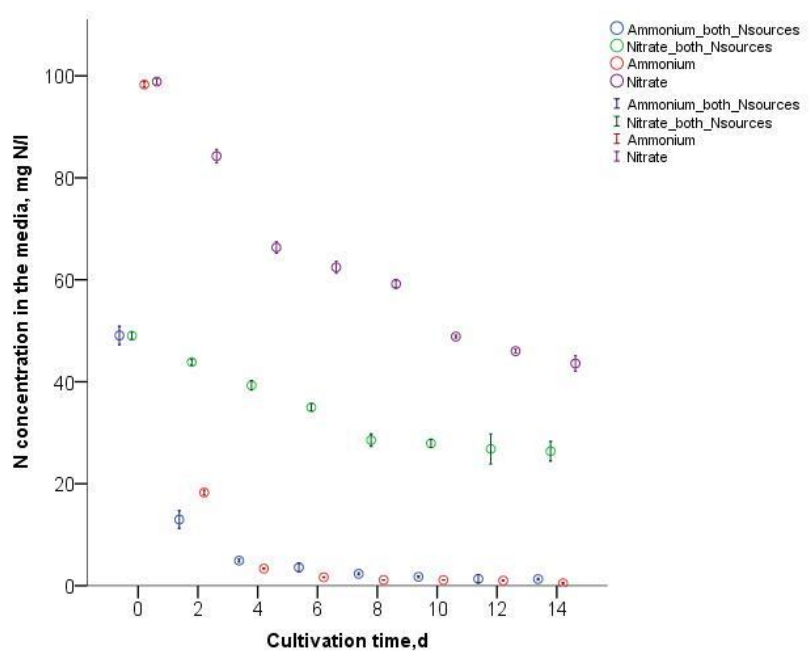

Fig. 3 - Nitrogen species concentration in the culture media over time

In terms of $\mathrm{P}$ assimilation, the concentration of $\mathrm{PO}_{4}{ }^{3-}$ declined rapidly within the first two days of the cultivation period in all the media tested independently of the $\mathrm{N}$ source used (Fig. 4); the microalgae were able to remove more than $99 \%$ of $\mathrm{PO}_{4}{ }^{3-}$ in all three experiments. It is because $\mathrm{P}$ is an essential nutrient for algal growth and metabolism that needed for producing cellular constituents such as phospholipids, nucleotides and nucleic acids [19]. The N concentration supply influences $\mathrm{P}$ storage in the algal biomass, and it is shown that $\mathrm{P}$ uptake by $C$. reinhardtii $11 / 32 \mathrm{C}$ was high due to high concentration of $\mathrm{N}$ in the medium, and the trend was similar with the $\mathrm{P}$ uptake by Chlorella and Scenedesmus $[20] . \mathrm{PO}_{4}^{3-}$ 
concentration was reduced from approximately $1 \mathrm{mg} \mathrm{P}^{-1}$ to $0.012-0.063 \mathrm{mg} \mathrm{P}^{-1}$ during the first four days and then completely removed below the analytical detection limit by day 14 .

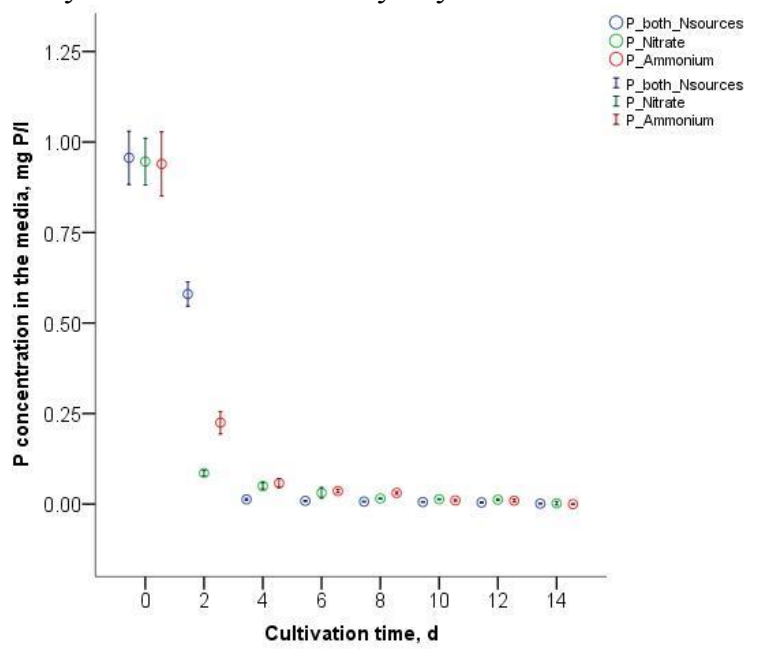

Fig. 4 - Remaining $P$ concentration under different nitrogen sources

\subsection{Effect of Different Inorganic Nitrogen Sources on P Uptake Rate of C.reinhardtii 11/32C}

P uptake by C.reinhardtii 11/32C during the exponential growth phase occurred from day 4 to 12 (Fig. 5). The net $\mathrm{P}$ uptake rate was calculated from data reporting suspended organic $\mathrm{P}$ in the media over time. Exponential regression coefficients $\left(\mathrm{R}^{2}\right)$ for the three experiments testing different nitrogen sources were $0.8,0.9$, and 0.5 , for experiments 1,2 and 3, respectively. The combination of $\mathrm{NO}_{3}{ }^{-}$and $\mathrm{NH}_{4}{ }^{+}$as $\mathrm{N}$ source influenced higher $\mathrm{P}$ uptake and produced higher concentrations of suspended organic $\mathrm{P}$ than using $\mathrm{NO}_{3}{ }^{-}$and $\mathrm{NH}_{4}{ }^{+}$on their own, although a short lag phase was found from day 4 to 6.

The effects caused by switching $\mathrm{NH}_{4}{ }^{+}$utilization in the first four days for $\mathrm{NO}_{3}{ }^{-}$afterwards enhanced net $\mathrm{P}$ uptake rates (Fig. 5(b)). This stressful condition triggered faster $\mathrm{P}$ uptake by microalgae, which continue day 14 . After day 4 , $\mathrm{P}$ uptake rate in Experiment 1 was $0.067 \mathrm{mg} \mathrm{P}^{-1} \mathrm{~d}^{-1}$, which is higher than $\mathrm{P}$ uptake rates found for experiments using $\mathrm{NO}_{3}{ }^{-}$or $\mathrm{NH}_{4}^{+}$; P uptake rates for tests 2 and 3 were 0.065 and $0.020 \mathrm{mg} \mathrm{P}^{-1} \mathrm{~d}^{-1}$ respectively.

Interestingly, when the content of $\mathrm{P}$ was plotted against the corresponding $\mathrm{N}$ content in dry biomass, $\mathrm{P}$ content varied from 0.2 to $2.3 \%$. The higher $\mathrm{P}$ content was about 1.8 to $2.3 \%$ when algae were cultivated in the media containing both $\mathrm{NO}_{3}{ }^{-}$and $\mathrm{NH}_{4}{ }^{+}$, and it corresponded to $\mathrm{N}$ content ranging from 3.0 to $4.2 \%$ (Fig. 6). From that, it is possible to infer that by using a media combining $\mathrm{NO}_{3}{ }^{-}$and $\mathrm{NH}_{4}{ }^{+}$as a nitrogen source, Ammonium is rapidly consumed by microalgae and then the shift into nitrate as $\mathrm{N}$ source accelerates $\mathrm{P}$ uptake and in-cell storage.

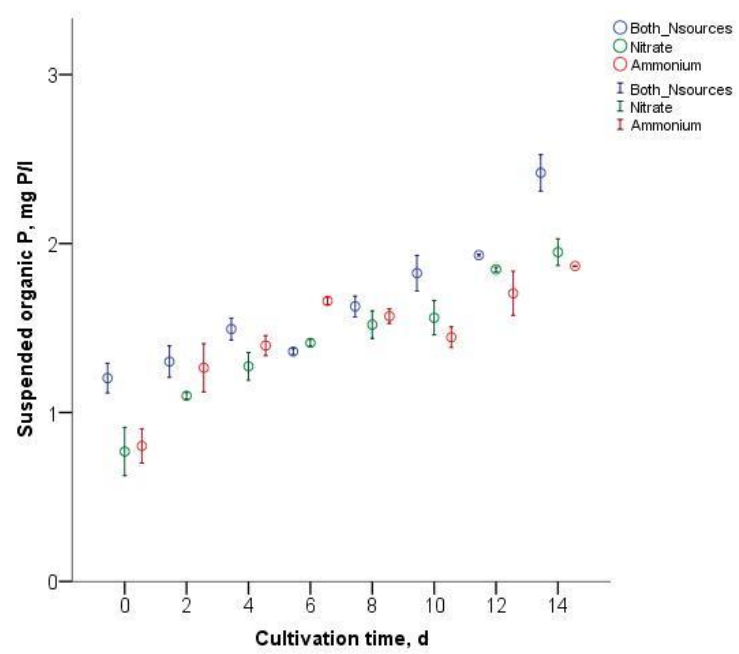

(a)

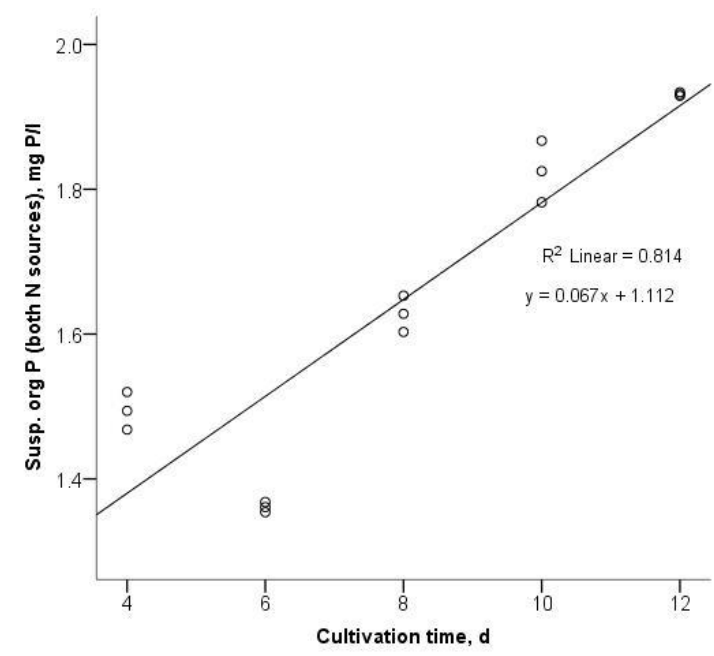

(b) 


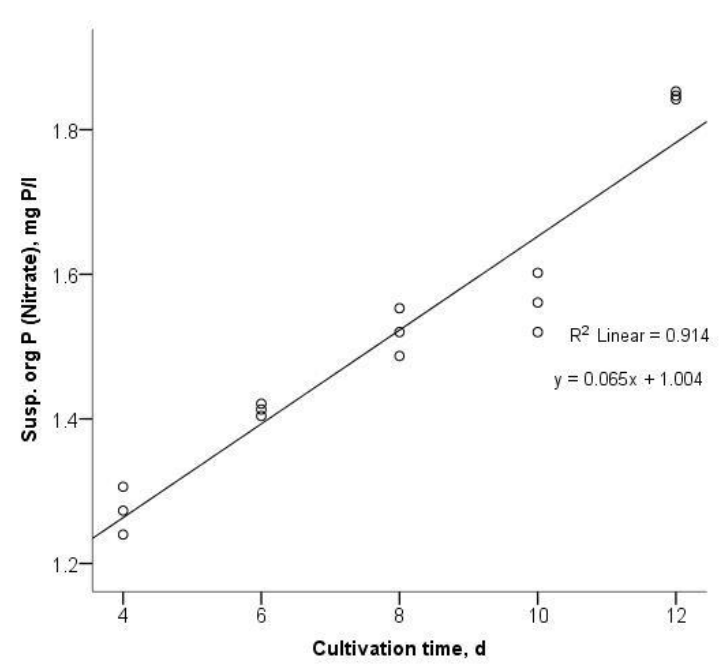

(c)

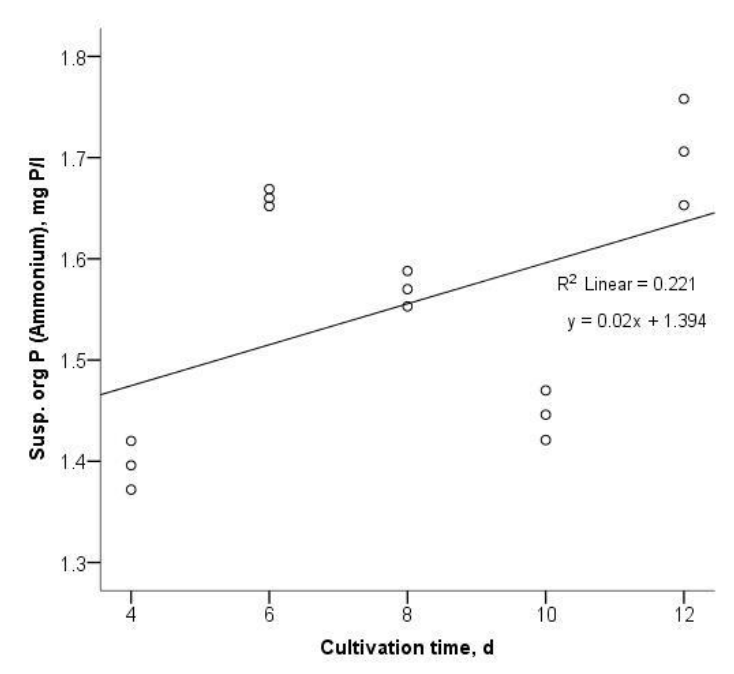

(d)

Fig. 5 - Suspended organic P over 14 days (a) and in exponential phase (b-d)

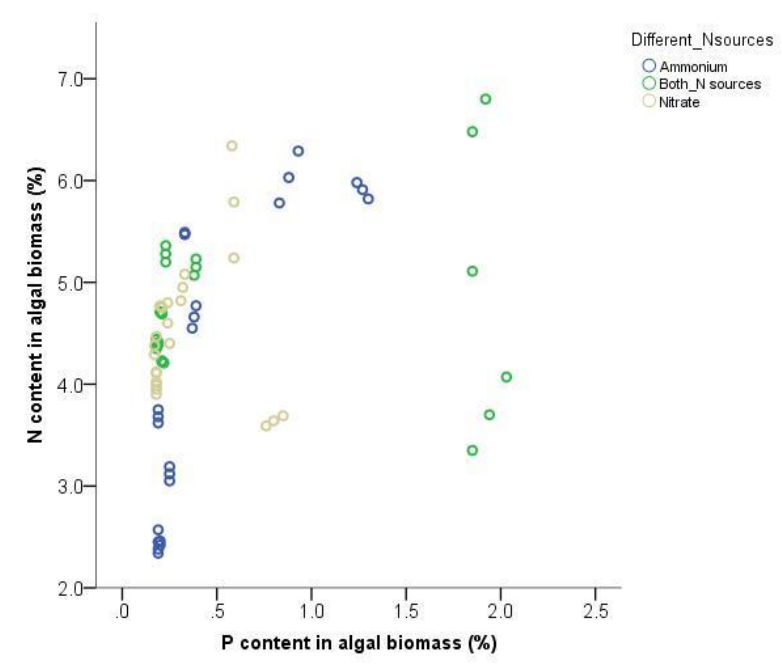

Fig. 6 - Phosphorus vs Nitrogen content in algal biomass (\% dry weight)

\section{Discussion}

This study aimed to identify favourable $\mathrm{N}$ sources for luxury $\mathrm{P}$ uptake and algal biomass production using C.reinhardtii $11 / 32 \mathrm{C}$ as a model organism. In the photosynthetic process, the utilization of $\mathrm{HCO}_{3}{ }^{-}$by microalgae will result in releasing hydroxyl ions $\left(\mathrm{HCO}_{3}{ }^{-} \rightarrow \mathrm{CO}_{2}+\mathrm{OH}^{-}\right)$[21]. As a typical response to inorganic carbon assimilation by microalgae, the $\mathrm{pH}$ increases as the photosynthetic activity progresses [10, 22]. Furthermore, regarding the presence of total ammonia in aqueous solution, the equilibrium between $\mathrm{NH}_{4}{ }^{+}$and $\mathrm{NH}_{3}$ is strongly $\mathrm{pH}$-dependent [23]. The shift of $\mathrm{NH}_{4}{ }^{+}$to $\mathrm{NH}_{3}$ occurs due to changes in $\mathrm{pH}$ above 8, which displaces the equilibrium from $\mathrm{NH}_{4}{ }^{+}$to $\mathrm{NH}_{3}$ [22]. The uncharged $\mathrm{NH}_{3}$ is most toxic because this form more soluble and readily transfer through the cell membranes than $\mathrm{NH}_{4}{ }^{+}$[23]. It is also well studied that $\mathrm{NH}_{4}{ }^{+}$inhibits microalgal growth at a concentration higher than $50 \mathrm{mg} \mathrm{N}^{-1}$ [24] or even at $28 \mathrm{mg} \mathrm{N}$ $1^{-1}[25]$, due to toxic effects caused by unionized ammonia $\left(\mathrm{NH}_{3}\right)$ [26].

Since $\mathrm{NH}_{3}$ is gas, it is potentially volatile and can be lost to the atmosphere. However, at the $\mathrm{pH}$ above eight, only $10 \%$ of total ammonia is present as a toxic form of $\mathrm{NH}_{3}$ and $90 \%$ as $\mathrm{NH}_{4}{ }^{+}$[27]. It indicates that microalgae can assimilate more $\mathrm{N}$ in forms of $\mathrm{NH}_{4}{ }^{+}$for their growth. The preference of $\mathrm{NH}_{4}{ }^{+}$over the other nitrogen sources also conveyed in Fig. 3 that shows $97 \%$ of $\mathrm{NH}_{4}{ }^{+}$utilized by C.reinhardtii $11 / 32 \mathrm{C}$. Valero and Mara [28] reported that $\mathrm{NH}_{3}$ volatilization was not the most critical mechanism on $\mathrm{N}$ removal process, because the $\mathrm{NH}_{3}$ and total $\mathrm{N}$ were removed mostly through microalgal biological uptake. They also confirmed that the removal rate of $\mathrm{NH}_{4}{ }^{+}$is faster than $\mathrm{NH}_{3}$ volatilization [29].

Measurements of $\mathrm{pH}$ values during this study confirmed that the $\mathrm{pH}$ of the algae culture was as high as 9.6 when $\mathrm{NH}_{4}{ }^{+}$was used as a sole nitrogen source. When other $\mathrm{N}$ sources were used, including a mix of $\mathrm{NO}_{3}{ }^{-}$and $\mathrm{NH}_{4}{ }^{+}$and $\mathrm{NO}_{3}{ }^{-}$, the recorded $\mathrm{pH}$ was 9.8 and 9.7, respectively. Higher $\mathrm{pH}$ cause the algal growth rate and biomass production of 
C.reinhardtii $11 / 32 \mathrm{C}$ in $\mathrm{NH}_{4}{ }^{+}$was lower than in the combination of $\mathrm{NO}_{3}{ }^{-}$and $\mathrm{NH}_{4}{ }^{+}$or $\mathrm{NO}_{3}{ }^{-}$. Similar effects were also observed in Chlorella sorokiniana [30] and Scenedesmus bijugatus [16].

Moreover, it was demonstrated that C.reinhardtii $11 / 32 \mathrm{C}$ preferred $\mathrm{NH}_{4}{ }^{+}$over $\mathrm{NO}_{3}{ }^{-}$in which $\mathrm{NH}_{4}{ }^{+}$removal was higher than $\mathrm{NO}_{3}$. Consequently, this preference for Ammonium at the concentration levels of the tests conducted did not prove to have a significant inhibitory effect on algal growth. In addition to different nitrogen sources, $\mathrm{P}$ uptake was better by microalgae when a combination of $\mathrm{NO}_{3}{ }^{-}$and $\mathrm{NH}_{4}{ }^{+}$were used. It might be caused by the stress effect of changing $\mathrm{N}$ source from ammonia to nitrate from the media. In contrast, $\mathrm{P}$ content in the algae grown in $\mathrm{NH}_{4}{ }^{+}$only was also higher than the figures found when the culture media contained only $\mathrm{NO}_{3}{ }^{-}$. It is because the algae using $\mathrm{NH}_{4}{ }^{+}$produced less biomass than when using $\mathrm{NO}_{3}{ }^{-}$and it may influence higher amounts of $\mathrm{P}$ content in algal cells.

Interestingly, P luxury uptake was also observed in C.reinhardtii 11/32C cultivated in the media containing both $\mathrm{NO}_{3}{ }^{-}$and $\mathrm{NH}_{4}{ }^{+}$. The resulting content of $\mathrm{P}$ found in the harvested algal biomass was $2.1 \%$, and it is higher than the typical amount of $\mathrm{P}$ reported in microalgae $(\approx 1 \% \mathrm{P})$. Hence, the combination of $\mathrm{NO}_{3}{ }^{-}$and $\mathrm{NH}_{4}{ }^{+}$has proved to be the best $\mathrm{N}$ source for enhancing algal growth and luxury $\mathrm{P}$ uptake in C.reinhardtii 11/32C.

\section{Conclusion}

C.reinhardtii $11 / 32 \mathrm{C}$ revealed to be able to assimilate several inorganic nitrogen sources for its growth, biomass production, and $\mathrm{P}$ uptake. In the present study, a combination of $\mathrm{NO}_{3}{ }^{-}$and $\mathrm{NH}_{4}{ }^{+}$for algal growth was found to be the most appropriate nitrogen source for C.reinhardtii 11/32C, which produced higher intracellular P uptake and algal biomass productivity. The combination of $\mathrm{NO}_{3}{ }^{-}$and $\mathrm{NH}_{4}{ }^{+}$also triggered the luxurious of $\mathrm{P}$ uptake, which $\mathrm{P}$ content in algal biomass was $2.1 \%$.

\section{Acknowledgement}

The first author thanks the Ministry of Research Technology and Higher Education, the Republic of Indonesia for the financial support, and the Institute of Public Health and Environmental Engineering (iPHEE), School of Civil Engineering, the University of Leeds UK for the facilities to conduct this research.

\section{References}

[1] Mata, T.M., A.A. Martins, and N.S. Caetano, Microalgae for biodiesel production and other applications: A review. Renewable \& Sustainable Energy Reviews, 2010. 14(1): p. 217-232

[2] Noue, J.D.L. and N.D. Pauw, The potential of microalgal bioechnology: A review of production and uses of microalgae. Biotech. Adv., 1988. 6: p. 725-770

[3] Pittman, J.K., A.P. Dean, and O. Osundeko, The potential of sustainable algal biofuel production using wastewater resources. Bioresource Technology, 2011. 102(1): p. 17-25

[4] Sivakumar, G., et al., Integrated green algal technology for bioremediation and biofuel. Bioresource Technology, 2012. 107: p. 1-9

[5] Wang, L.A., et al., Cultivation of Green Algae Chlorella sp in Different Wastewaters from Municipal Wastewater Treatment Plant. Applied Biochemistry and Biotechnology, 2010. 162(4): p. 1174-1186

[6] Ruiz-Marin, A., L.G. Mendoza-Espinosa, and T. Stephenson, Growth and nutrient removal in free and immobilized green algae in batch and semi-continuous cultures treating real wastewater. Bioresource Technology, 2010. 101(1): p. 58-64

[7] E, G.L., R.O. C, and S. B, Efficiency of ammonia and phosphorus removal from a Colombian agroindustrial wastewater by the microalgae Chlorella vulgaris and Scenedesmus dimorphus. Bioresource Technology, 1997. 60: p. $259-262$

[8] Faheed, F.A. and Z.A.-E. Fattah, Effect of Chlorella vulgaris as bio-fertilizer on growth parameters and metabolic aspects of Lettuce plant. Journal of Agriculture \& Social Sciences, 2008. 4: p. 165-169

[9] R.D., T., et al., Role of blue green algae biofertilizer in amelioratingthe nitrogen demand and fly-ash stress to the growth and yieldof rice (Oryza sativa L.) plants. Chemosphere, 2008. 70: p. 1919-1929.

[10] Li, X., et al., Growth and nutrient removal properties of a freshwater microalga Scenedesmus sp LX1 under different kinds of nitrogen sources. Ecological Engineering, 2010. 36(4): p. 379-381.

[11] Tam, N.F.Y. and Y.S. Wong, Effect of immobilized microalgal bead concentrations on wastewater nutrient removal. Environmental Pollution, 2000. 107(1): p. 145-151.

[12] Larsdotter, K., Wastewater treatment with microalgae - a literature review. Vatten, 2006. 62: p. 8.

[13] Cai, T., S.Y. Park, and Y.B. Li, Nutrient recovery from wastewater streams by microalgae: Status and prospects. Renewable \& Sustainable Energy Reviews, 2013. 19: p. 360-369.

[14] Fernandez, E. and A. Galvan, Nitrate assimilation in Chlamydomonas. Eukaryotic Cell, 2008. 7(4): p. 555-559.

[15] APHA, Standard methods for the examination of water and wastewater. 22 ed, ed. A. D.Eaton, L.S. Clesceri, and A.E. Grennberg. 2012, Washington, DC: American Public Health Association 
[16] Arumugam, M., et al., Influence of nitrogen sources on biomass productivity of microalgae Scenedesmus bijugatus. Bioresource Technology, 2013. 131: p. 246-249

[17] Dayananda, C., et al., Effect of media and culture conditions on growth and hydrocarbon production by Botryococcus braunii. Process Biochemistry, 2005. 40(9): p. 3125-3131.

[18] Xu, N., et al., Effects of nitrogen source and concentration on growth rate and fatty acid composition of Ellipsoidion sp. (Eustigmatophyta). Journal of Applied Phycology, 2001. 13.

[19] Zhu, S., et al., Luxury uptake of phosphorus changes the accumulation of starch and lipid in Chlorella sp under nitrogen depletion. Bioresource Technology, 2015. 198: p. 165-171.

[20] Beuckels, A., E. Smolders, and K. Muylaert, Nitrogen availability influences phosphorus removal in microalgaebased wastewater treatment. Water Research, 2015. 77: p. 98-106

[21] Lohman, E.J, et.al. Optimized inorganic carbon regime for enhanced growth and lipid accumulation in Chlorella vulgaris. Biotechnology for Biofuels, 2015. 8.

[22] Sawyer, C.N., P.L. McCarty, and G.F. Parkin, Chemistry for Environmental Engineering and Science. International Edition ed. 2003, New York: McGraw-Hill.

[23] Korner, S., et al., The effect of $\mathrm{pH}$ variation at the ammonium/ammonia equilibrium in wastewater and its toxicity to Lemna gibba. Aquatic Botany, 2001. 71(1): p. 71-78.

[24] Ip, S.Y., et al., Algal growth in primary settled sewage - The effects of 5 key variables. Water Research, 1982. 16(5): p. 621-632

[25] Tam, N.F.Y. and Y.S. Wong, Effect of ammonia concentrations on growth of Chlorella vulgaris and nitrogen removal from media. Bioresource Technology, 1996. 57(1): p. 45-50.

[26] 26. Kallqvist, T. and A. Svenson, Assessment of ammonia toxicity in tests with the microalga, Nephroselmis pyriformis, Chlorophyta. Water Research, 2003. 37(3): p. 477-484.

[27] 27. Collos, Y. and P.J. Harrison, Acclimation and toxicity of high ammonium concentrations to unicellular algae. Marine Pollution Bulletin, 2014. 80(1-2): p. 8-23.

[28] 28. Valero, M.A.C. and D.D. Mara, Nitrogen removal via ammonia volatilization in maturation ponds. Water Science and Technology, 2007. 55(11): p. 87-92.

[29] 29. Valero, M.A.C., Nitrogen Transformation Pathways and Removal Mechanisms in Domestic Wastewater Treatment by Maturation Ponds, in Shool of Civil Engineering. 2008, University of Leeds: Leeds. p. 145.

[30] 30. Kim, S., Y. Lee, and S.J. Hwang, Removal of nitrogen and phosphorus by Chlorella sorokiniana cultured heterotrophically in ammonia and nitrate. International Biodeterioration \& Biodegradation, 2013. 85: p. 511 -516 